\title{
Effect of Policy Reforms on Market Efficiency: Evidence from Dhaka Stock Exchange (DSE)
}

\author{
Md. Mahmudul Alam \\ Postgraduate Student \\ Institute for Environment and Development (LESTARI) \\ Universiti Kebangsaan Malaysia, Malaysia \\ E-mail: rony000@gmail.com \\ Shakila Yasmin \\ Lecturer \\ Institute of Business Administration \\ University of Dhaka, Bangladesh \\ Email: shakila@iba-du.edu \\ Mahmudur Rahman \\ Articled Student \\ Institute of Chartered Accountants Bangladesh \\ Dhaka, Bangladesh \\ Email: mahmudurrahman_du@yahoo.com \\ Md. Gazi Salah Uddin \\ Senior Lecturer \\ Department of Business Administration \\ East West University \\ 43, Mohakhali, Dhaka-1212, Bangladesh \\ Email: gsu@ewubd.edu
}

\section{Citation Reference:}

Alam, M.M., Yasmin, S., Rahman, M., Uddin, M.G.S. 2011. Effect of Policy Reforms on Market Efficiency: Evidence from Dhaka Stock Exchange, Economics Research International, Vol. 2011(1). Available at <http://www.hindawi.com/journals/econ/2011/864940/>, DOI:10.1155/2011/864940. (ISSN 2090-2131; Publisher- Hindawi Publishing Corporation)

This is a pre-publication copy.

The published article is copyrighted by the publisher of the journal. 


\title{
Effect of Policy Reforms on Market Efficiency: Evidence from Dhaka Stock Exchange (DSE)
}

\begin{abstract}
The paper tries to find evidence supporting the impact of continuous policy reforms on the market efficiency on the Dhaka Stock Exchange (DSE). Different policies formed/reformed from 1994 to 2005 were categorized in eleven groups depending on their time of issue and subject matter. To get the result, both non-parametric test (Kolmogrov-Smirnov normality test and Run test) and parametric test (Auto-correlation test, Auto-regression) has been performed. Analyses were done for each policy group, and it is found that formed/reformed policies for DSE during the study period failed to improve the market efficiency even in the weak form level.
\end{abstract}

Key Words: Market Efficiency; Random walk model; parametric test; non-parametric test; Dhaka Stock Exchange (DSE); Security Exchange Commission (SEC)

JEL Code: G14, G18

\section{INTRODUCTION}

The stock market is one of the most important sources for companies to raise money. This allows businesses to be publicly traded, or raise additional capital for expansion by selling shares of ownership of the company in a public market. The liquidity that an exchange provides affords investors the ability to quickly and easily sell securities. This is an attractive feature of investing in stocks, compared to other less liquid investments. History has shown that the price of shares and other assets is an important part of the dynamics of economic activity, and can influence or be an indicator of social mood. Rising share prices, for instance, tend to be associated with increased business investment and vice versa. Share prices also affect the wealth of households and their consumption. Therefore, a regulatory body (SEC) must keep an eye on the control and behavior of the stock market and, in general, on the smooth operation of security market functions. The smooth functioning of all these activities facilitates economic growth in ways that lower costs and enterprise risks and promote the production of goods and services as well as employment and thus contribute to increased prosperity.

After liberation when Dhaka Stock Exchange resumed trading activities in 1976, only 9 companies were listed having a paid up capital of Taka 137.52 million on the stock exchange (Chowdhury, 1994). By the end of 2005 number of Securities listed on DSE became 260 with market capital of Taka 228,574.85 million. As the market grew investment friendly rules and regulations were need to be introduced. The Securities \& Exchange Commission (SEC) was established on 8th June, 1993 under the Securities and Exchange Commission Act, 1993 to protect the interests of securities investors; to develop and maintain fair, transparent and efficient securities markets and to ensure proper issuance of securities and compliance with securities laws.

This has increased public interest to invest in the capital market. Foreign portfolio investment started to stream due to favorable regulatory conditions. In October 1996 a group of brokers, foreign portfolio managers and sponsors of listed companies manipulated stock 
prices. All Share Price Index crossed 3600 from less than 1000 within six weeks. As a result, at the end of 1996, few local and foreign investors got a huge gain. On the other hand, general public was trended to invest and faced a huge loss. In order to revive the confidence of the investors and to ensure the level playing field for all the market participants, the SEC formulated various policies for DSE to adopt in various times. But no research has been done to evaluate whether adaptation this policies have been fruitful (efficiency improvement) for the market or not. So this study tries to find out the effects of different policies on market efficiency, where policies are grouped into related topics and on time basis to determine their gradual effect of market efficiency for DSE. Therefore the basic research question is - Does the policy reform of the Securities \& Exchange Commission (SEC) in Bangladesh play an effective role to increase market efficiency of Dhaka Stock Exchange (DSE)?

\section{LITERATURE REVIEW}

Previous studies on testing weak form efficiency of developing and less developed stock markets like that to DSE there are two groups of findings. One group of researchers who find weak-form efficiency are Branes, 1986 (on the Kuala Lumpur Stock Exchange), Chan, Gup and Pan, 1992 (in major Asian markets), Dickinson and Muragu, 1994 (on the Nairobi Stock Exchange), and Ojah and Karemera 1999 (on the four Latin American countries market) despite the problems of thin trading. Another group of researchers who give evidence that developing and less developed markets are not efficient in weak-sense are Cheung, Wong and Ho (1993), on the stock market of Korea and Taiwan. In a World Bank study Claessens, Dasgupta and Glen (1995) suggest that stock prices in emerging markets violates weak form EMH. Similar findings are reported by Harvey (1994) for most emerging markets. Roux and Gilbertson (1978) and Poshakwale (1996) found the evidence of non-randomness stock price behavior and the market inefficiency (not weak-form efficient) on the Johannesburg stock Exchange and on the Indian market.

Few studies have already been conducted on Dhaka Stock Exchange (DSE). Hassan, Islam, and Basher (1999) studied on time-varying risk return relationship for Bangladesh by utilizing a unique data set of daily stock prices and returns. The result found that DSE equity returns held positive skewness, excess kurtosis and deviation from normality and the returns displayed significant serial correlation, implying the stock market is inefficient. Mobarek and Keasey (2000) concluded that Dhaka Stock Exchange does not follow random walk model and there are significant autocorrelation causes to DSE is not weak form efficient. Their result did not change for different sub-sample observations, without outlier, and for individual securities. Haque, Eunus, and Ahmed (2001) worked on the cumulative abnormal profit on the study period. He described the experience of DSE after the scam of November 1996 by applying CAPM and EMH. Based on the data four months before and four months after the automation, the paper measured risk-return performance, estimated SML for big capital and small capital companies before and after automation and tested EMH. The test results indicated that the market does not improve, and even after automation manipulation continued.

Kader and Rahman (2005) has no evidence that Dhaka Stock Exchange is weak form efficient by testing whether any technical trading strategy yielded abnormal profit or not by using technical trading rule (K\% filter rule). Islam and Khaled (2005) analyzed on the predictability of the share price in Dhaka Stock Exchange prior to the boom in 1996 and by using heteroscedasticity-robust tests found evidence in favor of short-term predictability of share prices in the Dhaka stock market prior to the 1996 boom, but not during the post-crash 
period. After thorough investigation it was concluded that the Securities and Exchange Commission were able to give more transparency of the Dhaka Stock Exchange by taking various steps.

Uddin and Alam (2007) examines the linear relationship between share price and interest rate, share price and growth of interest rate, growth of share price and interest rate, and growth of share price and growth of interest rate were determined through ordinary leastsquare (OLS) regression. For all of the cases, included and excluded outlier, they found that Interest Rate has significant negative relationship with Share Price and Growth of Interest Rate has significant negative relationship with Growth of Share Price in Dhaka Stock Market so that DSE is not weak form efficient. Alam, Alam and Uddin (2007) also shows that Dhaka Stock Exchange (DSE) is not weak form efficient through analyzing the randomness of market return, market risk-return relationships and the frequency of the market depth or liquidity. They found that Capital Asset Pricing Model (CAPM), which envisages the relationship between risk and the expected rate of return on a risky security, is unrelated in DSE market. As proper risk-return combination of the market is seems to be deficient in DSE and the market is not liquid, interest of the available investors are bring into being very insignificant.

The previous researchers measured DSE market efficiency by focusing on the transparency of DSE, effect of the new information on the market, effect of economic incidents on the market, any specific policy effect etc. But no study focused on the effect of policies on market efficiency. Here lies a crucial scope of work. Evaluating policies for effectiveness will obviously help policy makers and regulators. The findings may also identify some pose some challenges before the policy makers in order to address. That challenge will ultimately provoke further studies on the issue.

\section{METHODOLOGY}

All the policies of the market are grouped into eleven categories based on the timing and similarities of the issues involved in there. The total sample of this study includes 3,209 daily observations of DSE Daily General Price Index for the total sample period 1994 to 2005. The study examines the distribution of equity returns by dividing the sample period into eleven sub periods; periods before and after a group of policy was adopted for the market. Return distributions are studied by comparing the descriptive statistics of the Dhaka Stock Exchange Index (DSEI).

To confirm the distribution pattern of the stock return series, Kolmogrov Smirnov Goodness of Fitness test is used, which provides further evidence whether the distribution is normal or not. Kolmogrov Smirnov Goodness of fit test (K-S test) is a non-parametric test and is used to determine how well a random sample of data fits a particular distribution (uniform, normal and Poisson). The one sample K-S test compares the cumulative distribution function for a variable with a uniform and normal distributions to test whether the distributions are homogeneous or not. This paper uses both normal and uniform parameters to test the distribution. The run test is one of the non-parametric approaches to test and detect statistical dependencies (randomness) which may not be detected by the auto-correlation test. It is preferred to use run test to prove the random-walk model because the test ignores the properties of distribution. 
Moreover, the study investigates the parametric tests to examine the findings of nonparametric test. Auto-correlation test is a reliable measure for testing of either dependence or independence of random variables in a series. Kendall (1943, p. 412) computed the price changes at different lagged 1,2,3,4 time periods, that was popular among researchers (e.g., Laurence, 1986; Claessens, Dasgupta and Glen, 1995; Poshokwale, S. 1996; Nicolaas, 1997; Khaba, 1998; Mobarec, Asma 2002). Auto-correlation tests evidences whether the correlation coefficients are significantly different from zero or not. The serial correlation coefficient measures the relationship between the values of a random variable at time $t$ and its value in the previous period. The study also uses auto-regression techniques in time series analysis to examine if there is any non-zero significant relationship between current return series with the first lag (AR1) to eight lag (AR8) values of itself.

\section{MAJOR POLICIES ADOPTED IN DSE}

Various policies have been adopted by the SEC for DSE in various times. For the purpose of study these major policies are classified in 11 groups based on timing and related issues.

Group Policy 1: The laws of security were first introduced in 1920 by the then British government ruling India. By adding new provisions and deleting unnecessary provisions, the Security Act 1920 is still active in DSE. At present, Dhaka Stock Exchange (DSE) is a registered Public Limited Company and its activities are regulated by its Articles of Association and its own rules, regulations, and by-laws along with the Securities and Exchange Ordinance, 1969 where the procedures of issuing the stock capital has been included. The Investment Corporation was formulated according to the Investment Corporation Ordinance 1976. In this law the shares, shareholders, and the functions of the investment is properly defined. The Securities and Exchange Rule 1987 was introduced with the total rule procedure of the stock members and the stock transaction. The accounting procedures were also included in the new rule. The functions of the SEC and the formation procedure were introduced in SEC act 1993. According to SEC (Appeal) Regulation 1995, an appeal shall be filed in a prescribed form before any officer is specified by the commission on behalf and an appeal against more than one person should not be filed in one form.

Group Policy 2: According to the SEC (Prohibition of Insider Trading) Regulation- 1995, no insider personally or by others can provide information for the investment business. No sponsor, director or solicitor of a DSE registered company can purchase the share of that company without any prior permission of the authority. If anyone does so, his or her registration will be canceled out. The SEC Insider Trading Prohibition Act 1995 states that, no insider can give price sensitive information or any suggestion to others. Nobody can work as a merchant banker without prior registration. For registration, the banker needs manpower, capital and the experience of the banking service.

Group Policy 3: The public issue rule- 1999 states that, in the issue of prospectus the issuer needs to provide all material information and should include the risk factors. The company needs to provide the description of the asset and the future working plan. The company also needs to include the sponsors' name and about their executives' compensation.

Group Policy 4: According to The Listing Regulation of the DSE 97, no company can be registered in DSE without the registration under the public Ltd. company register and without maintain a minimum paid up capital of Taka 10,00,000. A listed company shall dispatch the interim dividend warrants to the shareholders concerned within 60 days from the date of 
declaration of such dividend in a meeting of the board of directors. A company will be de listed if its quoted price is below $50 \%$ of the face value.

Group Policy 5: As per The Right Issue Rule 1998, the price of the right share shall be determined in consultation with manager and licensed issue manager. Right share will not be issued more than the par value. Without the declaration by a credit rating company, no public debt or right issue is permitted. The clearing shall workout the due position of each and every member in every security on the category of A, B \& G.

Group Policy 6: Margin Rule 1999 states that, a member may extend his credit facility by making proper evidence. When the equity in a client's margin account falls below $150 \%$ of the debt balance, the member shall have to request for the additional margin to bring the equity not less than $150 \%$. According to The Depository Act 1999, a depository shall not be entitled to carry on any activities without registration, subject to the provision of the by laws, the transfer of every eligible share be in the depository account. The depository should not be a member of issuer. If anybody makes any distortion of the law, s/he will be imprisoned for a time no more than 5 years or fine or both.

Group Policy 7: DSE Automated Trading Regulation 1999 divides the trading period in five sessions and the work station will be available as decided by the council. The transaction orders are being divided in three types (price, volume \& validity). As decided by the DSE, investors' protection fund regulation established a fund. It is mandatory for all members to participate to the fund. The principal amount of the fund is given to the investor at the time of winding up and insolvency. According to the SEC (Stock dealer, stock broker \& permitted representative) regulation 2000, nobody can do transactions without registration. If the stock dealer or broker is not a member of the stock exchange or not a Chartered Company and the cash paid up capital is less than Taka 2.5 million, the SEC will cancel out the registration of them. DSE Member Margin Regulation 2000 states that, every member shall provide extra money as provided in addition to the security deposit.

Group Policy 8: According to SEC (Market Creation) Regulation 2000, only merchant bankers, schedule banks, registered stock dealers or brokers and the persons approved by the commission can create the market. Only the stocks of the listed companies can work as an instrument of the market creation. When a trust and its trustee are being registered under act and if the entrepreneur gives at least $10 \%$ of the first raising fund will be able to register under SEC (Mutual Fund) Regulation 2001. A director of the mutual fund will not be a merchant banker, portfolio manager or stock dealer at a time. The company, which has a minimum paid up capital Taka 30 million, no accumulated loss, operated for at least one year and regular in arranging the AGM can be listed directly to the DSE according to the regulation of 2001. Existing shareholders can sell their shares after listing not more than 50\% of their total holdings before the AGM after completing the first full accounting year.

Group Policy 9: Securities \& Exchange Commission (Over-The-Counter) Rules, 2001 states that on the request of the issuer company, when there is no public shareholder other than the sponsor, shall discontinue the OTC facilities of any security. The transaction of any security shall be done only by the registered stock dealer or broker and the exchange prominently discloses the security available in the OTC market. If any penal measure is found, the party will be penalized according to The SEC Ordinance 1969. 
Group Policy 10: According to The SEC Regulation 2002, a mass notice is needed to be given for acquiring the mentioned share by the person who already owned mentioned share or not. Here, mentioned share means $10 \%$ or more of the total share. According to SEC (Security Custodial Service) Act 2003, keeping the clients' security in custody, collected interest on behalf of the client and made security of all the information of the client is called the custodial service. Only the scheduled bank and the financial institution that have safety vault, required manpower, directors can be registered as a custodian of the security without any legal act. According to The Depository (User) Regulation 2003, in the event of any situation beyond the control of the depository, by consultation, the commission can take action and the depositors should send one copy of their procedure to the commission in that case.

Group Policy 11: Without the registration under The Act of SEC (Asset Backed Security Issue) Regulation 2004, nobody can issue or can work as a trustee of asset backed security. In case of mass offer, the security is needed to be listed under the OTC of stock exchange for three months. A trustee needs to be appointed for such kinds of issue under this act.

\section{THE RISK RETURN MODEL}

The study mainly considers the daily market returns as individual variable in time series analysis. DSE prepares daily price index from daily weighted-average price of daily transaction of each stock. Daily market returns $(\mathrm{R} \mathrm{mt})$ are calculated from the daily price indices such as follows:

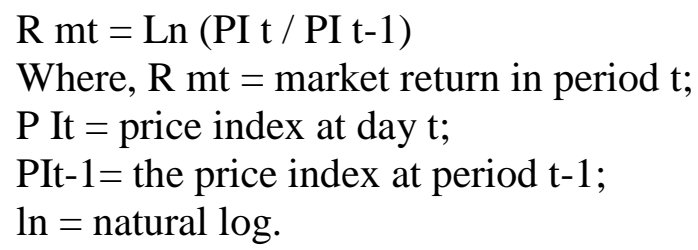

This calculation of market return is used in the efficiency test and systematic riskreturn analysis. The reasons to take logarithm returns are justified both theoretically and empirically. Theoretically, logarithmic returns are analytically more tractable when linking together 11 period returns to form returns over longer intervals. Empirically, logarithmic returns are more likely to be normally distributed which is a prior condition of standard statistical techniques (Strong, 1992). In case of market depth analysis, total market turnover is divided by total market capital to measure the frequency of regular transaction and liquidity of the market.

\section{EMPIRICAL RESULTS AND DISCUSSION}

Descriptive Statistics: The descriptive statistics of the market returns are presented on the table 1. For all the policy groups during the whole study period no Skewness value is equals to zero and no one Kurtosis value is less or equals to 3 . Therefore the frequency distribution of DSE stock return series indicates that the distribution is not normal. Even all the policies of DSE together are unable to ensure the normally distributed market return. So, one of the basic assumptions of random walk model - normal distribution return series is violated for DSE. 
Table 1: Descriptive Statistics of Market Return

\begin{tabular}{|c|c|c|c|c|c|c|c|c|}
\hline Group Policy & Time Range & Mean & Median & $\begin{array}{c}\text { Std. } \\
\text { Deviation }\end{array}$ & Minimum & Maximum & Skewness & Kurtosis \\
\hline Group Policy 1 & $\begin{array}{l}\text { 1/1/1994 - } \\
23 / 8 / 1995\end{array}$ & 0.00137 & 0.00021 & 0.01084 & -0.05440 & 0.06131 & 1.36222 & 9.01075 \\
\hline Group Policy 2 & $\begin{array}{l}1 / 1 / 1994- \\
23 / 6 / 1996\end{array}$ & 0.00131 & 0.00028 & 0.01020 & -0.05440 & 0.06131 & 1.12333 & 8.86883 \\
\hline Group Policy 3 & $\begin{array}{l}1 / 1 / 1994- \\
17 / 2 / 1997\end{array}$ & 0.00176 & 0.00060 & 0.01601 & -0.09197 & 0.12407 & 0.69752 & 9.25702 \\
\hline Group Policy 4 & $\begin{array}{l}\text { 1/1/1994 - } \\
23 / 5 / 1998\end{array}$ & 0.00028 & 0.00000 & 0.01873 & -0.09197 & 0.12407 & 0.26692 & 5.49108 \\
\hline Group Policy 5 & $\begin{array}{l}1 / 1 / 1994- \\
27 / 4 / 1999\end{array}$ & 0.00010 & -0.00007 & 0.01809 & -0.12141 & 0.12407 & 0.28424 & 7.82150 \\
\hline Group Policy 6 & $\begin{array}{l}1 / 1 / 1994- \\
6 / 12 / 1999\end{array}$ & 0.00010 & -0.00005 & 0.01730 & -0.12141 & 0.12407 & 0.29304 & 8.60001 \\
\hline Group Policy 7 & $\begin{array}{l}1 / 1 / 1994- \\
17 / 1 / 2001\end{array}$ & 0.00024 & 0.00000 & 0.01668 & -0.12141 & 0.12407 & 0.39213 & 10.05093 \\
\hline Group Policy 8 & $\begin{array}{c}1 / 1 / 1994- \\
11 / 12 / 2001\end{array}$ & 0.00032 & 0.00000 & 0.01736 & -0.12141 & 0.29215 & 2.58291 & 44.98335 \\
\hline Group Policy 9 & $\begin{array}{l}1 / 1 / 1994- \\
29 / 3 / 2002\end{array}$ & 0.00030 & 0.00000 & 0.01711 & -0.12141 & 0.29215 & 2.60533 & 46.06111 \\
\hline Group Policy 10 & $\begin{array}{l}1 / 1 / 1994- \\
15 / 10 / 2004\end{array}$ & 0.00049 & 0.00004 & 0.01539 & -0.12141 & 0.29215 & 2.67157 & 53.41117 \\
\hline Group Policy 11 & $\begin{array}{l}1 / 1 / 1994- \\
31 / 12 / 2005\end{array}$ & 0.00043 & 0.00005 & 0.01524 & -0.12141 & 0.29215 & 2.46361 & 50.82774 \\
\hline
\end{tabular}

Non- Parametric Tests (Kolmogrov Smirnov): Further, to confirm whether the distribution pattern of DSE is normal or not, Kolmogrov Smirnov Goodness of Fitness test has been used.

Table 2: Nonparametric Statistics (K-S Test for Normal Parameters) of Market Return

\begin{tabular}{|c|c|c|c|c|c|c|}
\hline Group Policy & Time Range & Absolute & Positive & Negative & K-S Z & Z-Tailed P \\
\hline Group Policy 1 & $\begin{array}{l}1 / 1 / 1994- \\
23 / 8 / 1995\end{array}$ & 0.15138 & 0.15138 & -0.11955 & 3.23265 & 0.00000 \\
\hline Group Policy 2 & $\begin{array}{l}1 / 1 / 1994- \\
23 / 6 / 1996\end{array}$ & 0.12724 & 0.12724 & -0.11377 & 3.22392 & 0.00000 \\
\hline Group Policy 3 & $\begin{array}{l}1 / 1 / 1994- \\
17 / 2 / 1997\end{array}$ & 0.14962 & 0.14962 & -0.14757 & 4.30541 & 0.00000 \\
\hline Group Policy 4 & $\begin{array}{l}1 / 1 / 1994- \\
23 / 5 / 1998\end{array}$ & 0.13705 & 0.13705 & -0.12388 & 4.64162 & 0.00000 \\
\hline Group Policy 5 & $\begin{array}{l}1 / 1 / 1994- \\
27 / 4 / 1999\end{array}$ & 0.14721 & 0.14721 & -0.12555 & 5.50215 & 0.00000 \\
\hline Group Policy 6 & $\begin{array}{l}1 / 1 / 1994- \\
6 / 12 / 1999\end{array}$ & 0.14980 & 0.14980 & -0.13060 & 5.91844 & 0.00000 \\
\hline Group Policy 7 & $\begin{array}{l}1 / 1 / 1994- \\
17 / 1 / 2001\end{array}$ & 0.15437 & 0.15437 & -0.13668 & 6.67380 & 0.00000 \\
\hline Group Policy 8 & $\begin{array}{l}1 / 1 / 1994- \\
11 / 12 / 2001\end{array}$ & 0.15772 & 0.15772 & -0.13890 & 7.24664 & 0.00000 \\
\hline Group Policy 9 & $\begin{array}{l}1 / 1 / 1994- \\
29 / 3 / 2002\end{array}$ & 0.15671 & 0.15671 & -0.13676 & 7.33512 & 0.00000 \\
\hline Group Policy 10 & $\begin{array}{l}1 / 1 / 1994- \\
15 / 10 / 2004\end{array}$ & 0.15051 & 0.15051 & -0.13672 & 8.11380 & 0.00000 \\
\hline Group Policy 11 & $\begin{array}{c}1 / 1 / 1994- \\
31 / 12 / 2005\end{array}$ & 0.14196 & 0.14196 & -0.13174 & 8.03809 & 0.00000 \\
\hline
\end{tabular}

Here one sample K-S test compares the cumulative distribution function for a variable with a normal testing whether the distributions are homogeneous. Table 2 shows that $\mathrm{Z}$ is increasing when more policy is added and as a result the data series is getting longer. For short sample period, $\mathrm{Z}$ value starts from 3.23 and probability for $\mathrm{Z}$ is always Zero, which indicates the frequency distribution of the daily price index of DSE does not follow normal distribution.

Table 3 shows the result of one sample K-S test that compares the cumulative distribution function for a variable with a uniform testing whether the distributions are 
homogeneous. For short sample period, $\mathrm{Z}$ value starts from 7.24 and this value increases when more policy is added; the probability for $\mathrm{Z}$ is always Zero, again indicates the frequency distribution of the daily price index of DSE is not normal.

Table 3: Nonparametric Statistics (K-S Test for Uniform Parameters) of Market Return

\begin{tabular}{|c|c|c|c|c|c|c|}
\hline Group Policy & Time Range & Absolute & Positive & Negative & K-S Z & Z-Tailed P \\
\hline Group Policy 1 & $\begin{array}{l}1 / 1 / 1994- \\
23 / 8 / 1995\end{array}$ & 0.33924 & 0.33924 & -0.32016 & 7.24416 & 0.00000 \\
\hline Group Policy 2 & $\begin{array}{l}\text { 1/1/1994 - } \\
23 / 6 / 1996\end{array}$ & 0.34735 & 0.34735 & -0.32290 & 8.80106 & 0.00000 \\
\hline Group Policy 3 & $\begin{array}{l}1 / 1 / 1994- \\
17 / 2 / 1997\end{array}$ & 0.41315 & 0.41315 & -0.28339 & 11.88833 & 0.00000 \\
\hline Group Policy 4 & $\begin{array}{l}\text { 1/1/1994 - } \\
23 / 5 / 1998\end{array}$ & 0.39744 & 0.39744 & -0.24489 & 13.46025 & 0.00000 \\
\hline Group Policy 5 & $\begin{array}{l}1 / 1 / 1994- \\
27 / 4 / 1999\end{array}$ & 0.34807 & 0.34807 & -0.33572 & 13.00963 & 0.00000 \\
\hline Group Policy 6 & $\begin{array}{l}\text { 1/1/1994 - } \\
6 / 12 / 1999\end{array}$ & 0.35326 & 0.35326 & -0.34117 & 13.95699 & 0.00000 \\
\hline Group Policy 7 & $\begin{array}{l}1 / 1 / 1994- \\
17 / 1 / 2001\end{array}$ & 0.35991 & 0.35991 & -0.35009 & 15.55971 & 0.00000 \\
\hline Group Policy 8 & $\begin{array}{c}1 / 1 / 1994- \\
11 / 12 / 2001\end{array}$ & 0.60220 & 0.60220 & -0.19395 & 27.66833 & 0.00000 \\
\hline Group Policy 9 & $\begin{array}{l}1 / 1 / 1994- \\
29 / 3 / 2002\end{array}$ & 0.60347 & 0.60347 & -0.19487 & 28.24733 & 0.00000 \\
\hline Group Policy 10 & $\begin{array}{l}1 / 1 / 1994- \\
15 / 10 / 2004\end{array}$ & 0.15051 & 0.15051 & -0.13672 & 8.11380 & 0.00000 \\
\hline Group Policy 11 & $\begin{array}{c}1 / 1 / 1994- \\
31 / 12 / 2005\end{array}$ & 0.61217 & 0.61217 & -0.20126 & 34.66179 & 0.00000 \\
\hline
\end{tabular}

Non- Parametric Tests (Run Test): Both Descriptive Statistic and Kolmogrov Smirnov test showed DSE return series violate one basic property of random walk model. In such case, run test is used to prove the random-walk model because the test ignores the distribution properties.

For the run test the null hypothesis is that the observed series is random where it converts total number of runs into a $\mathrm{Z}$ statistic. If the $\mathrm{Z}$ value is greater than or equal 1.96 , at 5\% significant level it is rejected (Sharma and Kennedy, 1977). Gujarati (1988) said at 5\% significant level one can reject the null hypothesis if the number of runs is equal or less than 9 , or equal or greater than 20 .

Table 4: Nonparametric Statistics (Run Test) of Market Return

\begin{tabular}{ccccc}
\hline Group Policy & Time Range & $\begin{array}{c}\text { Total Number of Runs } \\
\text { (Mean) }\end{array}$ & Z & $\begin{array}{c}\text { Asymp. Sig. (2- } \\
\text { tailed) }\end{array}$ \\
\hline Group Policy 1 & $1 / 1 / 1994-23 / 8 / 1995$ & 149 & -7.06076 & 0.00000 \\
Group Policy 2 & $1 / 1 / 1994-23 / 6 / 1996$ & 211 & -8.30394 & 0.00000 \\
Group Policy 3 & $1 / 1 / 1994-17 / 2 / 1997$ & 255 & -10.88698 & 0.00000 \\
Group Policy 4 & $1 / 1 / 1994-23 / 5 / 1998$ & 386 & -11.10742 & 0.00000 \\
Group Policy 5 & $1 / 1 / 1994-27 / 4 / 1999$ & 489 & -11.20018 & 0.00000 \\
Group Policy 6 & $1 / 1 / 1994-6 / 12 / 1999$ & 556 & -11.36364 & 0.00000 \\
Group Policy 7 & $1 / 1 / 1994-17 / 1 / 2001$ & 686 & -11.50943 & 0.00000 \\
Group Policy 8 & $1 / 1 / 1994-11 / 12 / 2001$ & 786 & -11.67586 & 0.00000 \\
Group Policy 9 & $1 / 1 / 1994-29 / 3 / 2002$ & 825 & -11.50251 & 0.00000 \\
Group Policy 10 & $1 / 1 / 1994-15 / 10 / 2004$ & 1092 & -13.27337 & 0.00000 \\
Group Policy 11 & $1 / 1 / 1994-31 / 12 / 2005$ & 1222 & -13.38751 & 0.00000 \\
\hline
\end{tabular}


In the table 4, it is clearly evident that all the numbers of run are greater than 20 and all the $\mathrm{Z}$ values are less than negative 1.96 and all $\mathrm{Z}$ values probability is zero, which rejects the null hypothesis. This implies that the return series of DSE does not follow random walk.

Parametric Tests (Autocorrelation Test): Autocorrelation is a good measurement for testing dependency of random variable in a series. The serial correlation coefficient measures the relationship between the values of a random variable at time $t$ and its value in the previous period.

The results of auto-correlation coefficients computed for the market return series are presented in table 5. It shows significant auto-correlation at different lags for all policy groups. For the policy group 1 where time period is short, there are significant (positive sign) auto-correlation coefficient at $1^{\text {st }}, 2^{\text {nd }}, 4^{\text {th }}$, and $5^{\text {th }}$ lag. All other policy groups also contain some positive autocorrelation coefficient. For the policy group 11 where time period is large, there are also significant (positive sign) auto-correlation coefficient at $1^{\text {st }}$, and $4^{\text {th }}$ lag.

Table 5: Parametric Statistics (Auto-correlation Test) of Market Return

\begin{tabular}{|c|c|c|c|c|c|c|c|c|c|}
\hline & Leg & 1 & 2 & 3 & 4 & 5 & 6 & 7 & 8 \\
\hline Group Policy 1 & Auto-correlation & $0.300 *$ & $0.163 *$ & 0.104 & $0.130^{*}$ & $0.246^{*}$ & 0.116 & 0.071 & 0.048 \\
\hline $1 / 1 / 1994-23 / 8 / 1995$ & Ljung-Box statistics & $41.3^{\$}$ & $53.5^{\$}$ & $58.5^{\S}$ & $66.3^{\$}$ & $94.2^{\$}$ & $100.4^{\$}$ & $102.8^{\$}$ & $103.8^{\$}$ \\
\hline Group Policy 2 & Auto-correlation & $0.285^{*}$ & $0.129 *$ & 0.089 & $0.125^{*}$ & $0.215^{*}$ & 0.106 & 0.056 & 0.038 \\
\hline 1/1/1994 - 23/6/1996 & Ljung-Box statistics & $52.5^{\S}$ & $63.2^{\$}$ & $68.3^{\$}$ & $78.5^{\S}$ & $108.4^{\$}$ & $115.7^{\$}$ & $117.7^{\$}$ & $118.6^{\$}$ \\
\hline Group Policy 3 & Auto-correlation & $0.510 *$ & $0.196^{*}$ & 0.027 & 0.058 & $0.085^{*}$ & 0.049 & 0.020 & 0.066 \\
\hline 1/1/1994 - 17/2/1997 & Ljung-Box statistics & $215.9^{\$}$ & $247.9^{\$}$ & $248.6^{\$}$ & $251.3^{\$}$ & $257.3^{\$}$ & $259.3^{\$}$ & $259.6^{\$}$ & $263.3^{\$}$ \\
\hline Group Policy 4 & Auto-correlation & $0.400 *$ & 0.028 & 0.044 & $0.109 *$ & 0.047 & -0.013 & 0.043 & 0.062 \\
\hline $1 / 1 / 1994-23 / 5 / 1998$ & Ljung-Box statistics & $184.0^{\$}$ & $184.9^{\$}$ & $187.1^{\$}$ & $200.9^{\$}$ & $203.5^{\$}$ & $203.6^{\$}$ & $205.8^{\$}$ & $210.2^{\$}$ \\
\hline Group Policy 5 & Auto-correlation & $0.366^{*}$ & 0.010 & 0.018 & $0.108^{*}$ & 0.057 & 0.018 & 0.032 & 0.051 \\
\hline 1/1/1994 - 27/4/1999 & Ljung-Box statistics & $187.1^{\$}$ & $187.3^{\$}$ & $187.7^{\$}$ & $204.0^{\$}$ & $208.5^{\$}$ & $208.9^{\$}$ & $210.4^{\$}$ & $214.0^{\$}$ \\
\hline Group Policy 6 & Auto-correlation & $0.360 *$ & 0.011 & 0.017 & $0.104 *$ & 0.054 & 0.018 & 0.032 & 0.050 \\
\hline 1/1/1994 - 6/12/1999 & Ljung-Box statistics & $203.0^{\$}$ & $203.2^{\$}$ & $203.6^{\$}$ & $220.6^{\$}$ & $225.2^{\$}$ & $225.7^{\$}$ & $227.3^{\$}$ & $231.3^{\$}$ \\
\hline Group Policy 7 & Auto-correlation & $0.337^{*}$ & 0.001 & 0.037 & $0.103^{*}$ & 0.062 & -0.002 & 0.013 & 0.042 \\
\hline $1 / 1 / 1994-17 / 1 / 2001$ & Ljung-Box statistics & $212.4^{\$}$ & $212.4^{\$}$ & $215.0^{\$}$ & $235.0^{\S}$ & $242.2^{\$}$ & $242.2^{\$}$ & $242.6^{\$}$ & $245.9^{\$}$ \\
\hline Group Policy 8 & Auto-correlation & $0.275^{*}$ & -0.009 & 0.045 & $0.087^{*}$ & 0.055 & -0.010 & 0.009 & 0.031 \\
\hline $\begin{array}{c}1 / 1 / 1994- \\
11 / 12 / 2001\end{array}$ & Ljung-Box statistics & $159.5^{\$}$ & $159.7^{\$}$ & $164.0^{\$}$ & $180.1^{\$}$ & $186.5^{\$}$ & $186.7^{\$}$ & $186.9^{\$}$ & $188.9^{\$}$ \\
\hline Group Policy 9 & Auto-correlation & $0.274 *$ & -0.010 & 0.046 & $0.088^{*}$ & 0.054 & -0.010 & 0.010 & 0.032 \\
\hline $1 / 1 / 1994-29 / 3 / 2002$ & Ljung-Box statistics & $164.6^{\$}$ & $164.8^{\$}$ & $169.4^{\$}$ & $186.3^{\$}$ & $192.7^{\$}$ & $192.9^{\$}$ & $193.2^{\$}$ & $195.4^{\$}$ \\
\hline Group Policy 10 & Auto-correlation & $0.269^{*}$ & -0.006 & 0.049 & $0.081 *$ & 0.053 & -0.011 & 0.015 & 0.033 \\
\hline $\begin{array}{c}1 / 1 / 1994- \\
15 / 10 / 2004\end{array}$ & Ljung-Box statistics & $210.0^{\$}$ & $210.1^{\$}$ & $217.1^{\$}$ & $236.3^{\$}$ & $244.4^{\$}$ & $244.7^{\$}$ & $245.4^{\$}$ & $248.5^{\$}$ \\
\hline Group Policy 11 & Auto-correlation & $0.256^{*}$ & -0.011 & 0.046 & $0.077 *$ & 0.048 & -0.009 & 0.012 & 0.025 \\
\hline $\begin{array}{c}1 / 1 / 1994- \\
31 / 12 / 2005\end{array}$ & Ljung-Box statistics & $210.5^{\$}$ & $210.9^{\$}$ & $217.6^{\S}$ & $236.6^{\mathrm{s}}$ & $244.1^{\$}$ & $244.3^{s}$ & $244.8^{\$}$ & $246.8^{\S}$ \\
\hline
\end{tabular}

Note: * denotes significant auto-correlation at two standard error limits; ${ }^{\$}$ denotes LB statistics significant at $1 \%$ level of significance.

The presence of non-zero auto-correlation coefficients in the market return series suggests that there is a serial dependence between the values. In addition, the nonzero autocorrelation of the series is associated with Ljung -Box Q statistics, which are jointly 
significant at $1 \%$ level at 8 degrees of freedom (lags), suggest the return series does not follow random walk model.

Parametric Tests (Auto-Regression Test): The results presented in the table 6, show a significant auto-regression coefficient at first and second lags at $1 \%$ level of significance which proves that the series is not independent and the market is not weak form efficient. The result does not differ significantly for the sample into eleven policy groups. For the policy groups 1 and 2, when the sample size is small, it shows a significant auto-regression coefficient for the first lag but not for second lag and all other policies has both first and second lag significant auto-regression coefficient. So in all cases it has been proved that the return series of DSE is not independent.

Table 6: Parametric Statistics (Auto-regression Test) of Market Return

\begin{tabular}{|c|c|c|c|c|c|}
\hline Policy & Model & Coefficient & SEB & T-Ratio & Approx. Prob. \\
\hline & Constant & $0.0009^{\$}$ & 0.0005 & 1.8078 & 0.0713 \\
\hline \multirow[t]{3}{*}{ Group Policy 1} & Market Return (t-1) & $0.2786^{*}$ & 0.0469 & 5.9439 & 0.0000 \\
\hline & Market Return (t-2) & 0.0645 & 0.0463 & 1.3934 & 0.1642 \\
\hline & Constant & $0.0009^{\$}$ & 0.0004 & 2.2631 & 0.0240 \\
\hline \multirow[t]{3}{*}{ Group Policy 2} & Market Return (t-1) & $0.2735^{*}$ & 0.0396 & 6.9079 & 0.0000 \\
\hline & Market Return (t-2) & 0.0395 & 0.0392 & 1.0072 & 0.3142 \\
\hline & Constant & $0.0009^{\$}$ & 0.0005 & 1.9084 & 0.0567 \\
\hline \multirow[t]{3}{*}{ Group Policy 3} & Market Return (t-1) & $0.5563^{*}$ & 0.0347 & 16.0421 & 0.0000 \\
\hline & Market Return (t-2) & $-0.0868^{\S}$ & 0.0348 & -2.4957 & 0.0128 \\
\hline & Constant & 0.0002 & 0.0005 & 0.4109 & 0.6812 \\
\hline \multirow[t]{3}{*}{ Group Policy 4} & Market Return (t-1) & $0.4660^{*}$ & 0.0293 & 15.9274 & 0.0000 \\
\hline & Market Return (t-2) & $-0.1595^{*}$ & 0.0292 & -5.4590 & 0.0000 \\
\hline & Constant & 0.0001 & 0.0004 & 0.1704 & 0.8647 \\
\hline \multirow[t]{3}{*}{ Group Policy 5} & Market Return (t-1) & $0.4181^{*}$ & 0.0265 & 15.7713 & 0.0000 \\
\hline & Market Return (t-2) & $-0.1438^{*}$ & 0.0265 & -5.4316 & 0.0000 \\
\hline & Constant & 0.0001 & 0.0004 & 0.1860 & 0.8525 \\
\hline \multirow[t]{3}{*}{ Group Policy 6} & Market Return (t-1) & $0.4098^{*}$ & 0.0251 & 16.3321 & 0.0000 \\
\hline & Market Return (t-2) & $-0.1381^{*}$ & 0.0251 & -5.5113 & 0.0000 \\
\hline & Constant & 0.0002 & 0.0004 & 0.4985 & 0.6182 \\
\hline \multirow[t]{3}{*}{ Group Policy 7} & Market Return (t-1) & $0.3795^{*}$ & 0.0230 & 16.5299 & 0.0000 \\
\hline & Market Return (t-2) & $-0.1274^{*}$ & 0.0229 & -5.5556 & 0.0000 \\
\hline & Constant & 0.0003 & 0.0004 & 0.7031 & 0.4821 \\
\hline \multirow[t]{3}{*}{ Group Policy 8} & Market Return (t-1) & $0.3000^{*}$ & 0.0217 & 13.8354 & 0.0000 \\
\hline & Market Return (t-2) & $-0.0928^{*}$ & 0.0217 & -4.2816 & 0.0000 \\
\hline & Constant & 0.0002 & 0.0004 & 0.6705 & 0.5026 \\
\hline \multirow[t]{3}{*}{ Group Policy 9} & Market Return (t-1) & $0.2991^{*}$ & 0.0213 & 14.0504 & 0.0000 \\
\hline & Market Return (t-2) & $-0.0924 *$ & 0.0213 & -4.3470 & 0.0000 \\
\hline & Constant & 0.0004 & 0.0003 & 1.4160 & 0.1569 \\
\hline \multirow[t]{3}{*}{ Group Policy 10} & Market Return (t-1) & $0.2914^{*}$ & 0.0185 & 15.7568 & 0.0000 \\
\hline & Market Return (t-2) & $-0.0850^{*}$ & 0.0185 & -4.5978 & 0.0000 \\
\hline & Constant & 0.0003 & 0.0003 & 1.3386 & 0.1808 \\
\hline \multirow[t]{2}{*}{ Group Policy 11} & Market Return (t-1) & $0.2774^{*}$ & 0.0176 & 15.7498 & 0.0000 \\
\hline & Market Return (t-2) & $-0.0832 *$ & 0.0176 & -4.7274 & 0.0000 \\
\hline
\end{tabular}

Note: $*$ denotes significant at $1 \%$ level and ${ }^{\$}$ denotes significant at $10 \%$ level. 


\section{CONCLUSIONS}

The assumption that stock returns series are random is basic to the Efficient Market Hypothesis and Capital Asset Pricing Models. The results of the analysis differ from the findings of idealized efficient market. So, the overall findings of this research are also in line with the past research outcomes on DSE. The frequency distribution of the stock prices in DSE does not follow a normal or uniform distribution. This result is confirmed by the nonparametric K-S test. The results of run test and auto-correlation coefficient tests indicate that the non-random nature of the series violate the assumption of null hypothesis that the market is efficient in weak form. Further test on the predictability of past values in the series using time series statistical techniques such as auto-regression model confirms the previous findings and the results are consistent with all the categories of the eleven policy groups.

In overall analysis, it is observed that all of the existing policy of DSE \& SEC cannot ensure market efficiency, not even weak form. Continuous and frequent policy changes have no impact on market efficiency in DSE. Present policies of DSE cannot ensure proper return in the market. Both types of active and passive investors are not behaving randomly as investors' confidence on the policy of DSE is very low. Therefore acute attention must be given on the issues of policy reform and formulation such that the policies can play a good role to improve the reliability and efficiency of DSE.

\section{REFERENCES}

Alam, M. M., Alam, K. A. and Uddin, Md. G. S. (2007), "Market Depth and Risk Return Analysis of Dhaka Stock Exchange: An Empirical Test of Market Efficiency", ASA Business Review, Vol. 1(1), pp. 93-101, July- December.

Branes, Paul (1986), "Thin trading and stock market efficiency: A case of the Kuala Lumpur Stock Exchange", Journal of Business Finance \& Accounting, Vol. 13(4), pp. 609617.

Chan, Kam C., Gup, Benton E., and Pan, Ming-shiun (1992), "An Empirical Analysis of Stock Prices in Major Asian Markets and United States”, The Financial Review, Vol. 27(2), pp.89- 307, May.

Cheung, Yan -Leung, Wong, Kie-Ann, and Ho, Yan-Ki (1993), "The pricing of risky assets in two emerging Asian markets- Korea and Taiwan", Applied Financial Economics, Vol. 3(4), pp.315-324, December.

Chowdhury, A. R. (1994), "Statistical Properties of Daily Returns from Dhaka Stock Exchange," The Bangladesh Development Studies, Vol. 22(4), pp. 61-76.

Claessens, S., Dasgupta, S. and Glen, J. (1995), "Return Behaviour in Emerging Stock Markets", The World Bank Economic Review, Vol. 9(1), pp.131-151.

Dickinson, John P. and Muragu, K. (1994), "Market Efficiency in Developing Countries: A case study of the Nairobi Stock Exchange", Journal of Business Finance \& Accounting, Vol. 21(1), pp. 133-150, January.

Gujarati, Damodar N. (1988), Basic Econometrics, $2^{\text {nd }}$ ed., pp.691, Mcgraw -Hill.

Haque, M. S., Eunus, R. and Ahmed, M. (2001) "Risk Return \& Market Efficiency in Capital Market under Distress: Theory and Evidence from DSE", Chittagong Stock Exchange Publication, Quarter-1. Available at <http://www.csebd.com/cse/Publications/portfolio_Q1_2001/risk_\%20return.html>, (Accessed on March 22, 2006).

Harvey, Campbell R. (1994), "Conditional Asset allocation in Emerging Markets”, Working Paper No.4623, Cambridge, MA. 
Hassan, M. Kabir; Islam, M. Anisul and Basher, Syed Abul (1999), "Market Efficiency, Time-Varying Volatility and Equity Returns in Bangladesh Stock Market", Working Papers 2002-06, York University, Department of Economics, revised Jun 2002. Available

<http://dept.econ.yorku.ca/research/workingPapers/working_papers/DSE.pdf>, (Accessed on March 22, 2006).

Islam, Ainul and Khaled, Mohammed (2005), "Tests Of Weak-Form Efficiency Of The Dhaka Stock Exchange”, Journal Of Business Finance \& Accounting, Vol. 32(7-8), pp.1613-1624, September/October.

Kader, A. A., and Rahman, A. F. M A. (2005), "Testing the Weak-Form Efficiency of an Emerging Market: Evidence from the Dhaka Stock Exchange of Bangladesh", AIUB Journal, Vol. 4(2), August.

Kendall, M. G. (1943), The advanced Theory of Statistics, Vol.1, London: Griffin.

Khababa, N. (1998), "Behavior of stock prices in the Saudi Arabian Financial Market: Empirical research findings", Journal of Financial Management \& Analysis, Volume 11(1), Jan-June, pp. 48-55.

Laurence, M. M.(1986), "Weak-form efficiency in the Kuala Lumpur and Singapore Stock Markets", Journal of Banking and Finance, vol. 10, pp.431-445.

Mobarek, A. and K. Keasey (2002), "Weak-Form Market Efficiency of an Emerging Market: Evidence from Dhaka Stock Market of Bangladesh". Working Paper. Available at < http://www.bath.ac.uk/Centres/CDS/enbs-papers/mobarek_new.htm>, (Accessed on March 12, 2006).

Mobarek, Asma and Keasey, Keavin (2000), "Weak-form market efficiency of an emerging market: Evidence from Dhaka Stock Market of Bangladesh", Paper presented at the ENBS Conference held on Osio, May. Avaialable at $<$ http://www.bath.ac.uk/Centres/CDS/enbs-papers/mobarek_new.html>, (Accessed on March 22, 2006).

Nicolaas, G. (1997), "Share market efficiency: Tests using daily data for Australia and New Zealand", Applied Financial Economics, vol.7. Pp.645-657.

Ojah, Kalu and Karemera, D. (1999), "Random walks and Market efficiency Tests of Latin Amaeracan Emerging Equity Markets: A Revisit", The Financial Review, Vol. 34(2), pp. 57-72.

Poshakwale S. (1996), "Evidence on the Weak-form efficiency and the day of the week effect in the Indian Stock Market", Finance India, Volume 10(3), September, pp. 605616.

Poshakwale, S. (1996), "Evidence on the Weak-form efficiency and the day of the week effect in the Indian Stock Market", Finance India, Vol. 10(3), pp. 605-616, September.

Roux, F. J. P. and Gilbertson, D. P. (1978), "The behavior of share prices on the Johannesburg Stock Exchange", Journal of Business Finance and Accounting, Vol. 5(2), pp. 223-232.

Sharma, J.L. and Kennedy, Robert. E. (1977), "A Comparative Analysis of Stock Price Behavior in Bombay, London and New York Stock Exchanges", Journal of Financial and Quantitative Analysis, Vol. 12(3), pp.391-413, September.

Strong, N. (1992), "Modeling Abnormal Returns: A Review Article", Journal of Business, Finance and Accounting, Vol. 19(4), pp.533-553, June.

Uddin, M. G. S. and Alam, M. M. (2007), "The Impacts of Interest Rate on Stock Market: Empirical Evidence from Dhaka Stock Exchange", South Asian Journal of Management and Sciences, Vol. 1(2), pp. 123-132. 